\title{
Attitudes toward English among AL-Quds Open University Students in Tulkarm Branch
}

\author{
Ziyad Ahmed Ibraheem Tanni ${ }^{1, *}$ \\ ${ }^{1}$ AL-Quds Open University, Tulkarm Branch, Tulkarm, Palestine \\ *Correspondence: AL-Quds Open University, Tulkarm Branch, P.O.Boox 65, Tulkarm, Palestine. E-mail: \\ ztanni@qou.edu
}

Received: March 15, 2015

Accepted: June 8, 2015 Online Published: June 14, 2015

doi:10.5430/wje.v5n3p139

URL: http://dx.doi.org/10.5430/wje.v5n3p139

\begin{abstract}
The aim of this study is to identify the attitudes toward English among AL-Quds Open University students in Tulkarm Branch, Palestine. To achieve this purpose, the researcher used a questionnaire composed of 30 items distributed to 70 male and 110 female students in four faculties: Education, Social Development, Administrative Sciences and Technology and Applied Sciences in AL- Quds Open University, Tulkarm Branch. These students are in different study levels (years). This study was conducted during the first semester of the academic year 2014-2015. The researcher used different statistical procedures which fit the collected data. The results of the study revealed that most of the students in AL- Quds Open University, Tulkarm Branch have positive attitudes towards English. Moreover, the attitude of females toward English is more positive than the attitude of males. There are significant differences in attitudes towards English among students due to academic level. There are no significant differences in attitudes toward English among students due to faculty. Based on the results, the researcher recommends the following: First, universities are requested to offer a reasonable number of English communication courses to give students a chance to practice and improve their language so as to make the language favorable for them and have a good attitude toward it. Second, teachers are required to encourage students to get engaged in co-curricular English activities in special meetings among themselves to use English in speaking and writing.
\end{abstract}

Keywords: attitudes; foreign language; undergraduate students.

\section{Introduction}

English is an international and even it is the leading foreign language enjoying a prestigious position in many countries including Palestine. Donitsa- Schmidt et al. (2004) maintained that different aspects of language attitudes have also been studied such as the relation between attitudes and motivation. English in Palestine is taught as a foreign language and students are instrumentally motivated. Ardeo (2003) stated that learning a foreign language is a complex process which involves a large number of dependent and independent variables. Starks \& Paltridge (1996: 218) believed that learning a language is closely related to the attitudes towards the languages.

Mantle- Bromley (1995) argued that teachers need to acknowledge and respect students' attitudes, beliefs and expectations and help them overcome any harmful perceptions and blocks, as well as enhance students' awareness of their personal weaknesses and strengths and of their strategic knowledge).

It has been identified that learner's attitudes toward a target language and its speakers as well as the use of that language play a central role in determining levels of success for the learning and acquision of that language. According to Skehan (1989), attitudes are one of the several components of affective variables of language learning. Wenden (1991) sees attitudes as including three components: First, attitudes tend to have a cognitive component. This could involve beliefs or perception about the objects or situations related to the attitude. Second, attitudes have an evaluative component. This means that the objects or situations related to the attitude may generate like or dislike. Third, attitudes have a behavioral component, i.e. certain attitudes tend to prompt learners to adopt particular learning behaviors. Lindemann (2002) maintained that attitude is a construct that explains linguistic behavior in particular. Allport (1935as cited in Baker, 1992:10) defines, 'attitude is a mental or neutral state of readiness, organized through experience, exerting a directive or dynamic influence upon individual's response to all objects and situations with which it is related". 
Gardner (1985:10) sees attitudes as components of motivation in language learning. According to him, "motivation refers to the combination of effort plus desire to achieve the goal of learning the language plus favorable attitudes toward learning the language".

This study will not be intended to explain all the factors involved in learning a foreign language but to focus on a specific aspect which is the attitude of adult university students toward English and aims, in particular, at investigating the attitudes of undergraduate students in AL- Quds Open University - Tulkarm Branch.

\section{Reviewing the Related Literature}

The researcher reviewed the available literature relevant to the topic of the study. He found out that many studies have been carried out on language attitudes over the years across the world. To mention some of these studies:

Borromeo, Samonte (1981) studied Filipino college students' attitudes toward English. Results showed that students favor English. Their attitudes were influenced by their integrative motivation as they can easily identify themselves with culture. Moreover, the study showed that the attitudes were conditioned by the choice of profession/ vocation and age.

Buschenhofen in his survey study (1998) in which he assessed the attitudes of year 12 and final-year university students in Papua New Guinea towards English, he found out that the students generally have positive attitudes towards English even though between the two groups there are some significant attitudinal differences in terms of specific English language contexts.

Warden and Lin (1998) investigated Taiwanese non- EFL major students' attitudes. The results revealed that past learning processes and different language skills, teaching methods, interests affect attitudes of the students and their perspectives towards English language learning.

Al-Haq (2000) in his study he tried to investigate changes in attitudes of Jordanian university students to the Hebrew language. He found that motivation towards learning Hebrew among the Jordanian University students is apparently instrumentally- oriented, i.e. they are religiously and nationally motivated.

EL-Dash and Busnardo (2001) they studied Brazilian attitudes toward English. Results revealed that the majority of adolescents favor English to the Portuguese language in terms of status and solidarity.

Kwofie (2001) compared the University of Cape Coast students' attitudes towards English, Pidgin and Ghanaian languages. The findings revealed that students had favorable attitudes toward English and unfavorable attitudes towards Pidgin and Ghanaian Languages. She believed that English was favored because of its communicative, instrumental, integrative and educational values.

Marley, (2003) carried out a study on Language attitudes among high school students and teachers in Khouribga. The findings showed that both students and teachers appear to be widely in favor of return to Arabic- French bilingualism within the education system and approve decision to introduce foreign language at an earlier stage.

Guerini (2007) in a study done in the University of Ghana to survey attitudes towards language use in education among students of the University of Ghana, concluded that the introduction of a local language as the teaching medium in various levels of the local educational system would be opposed by students who think that the local languages are unfit for use in formal, technical and specialized domains, and value a command of English as one of the most important skills needed for formal education.

Shaw (2007) studied the attitudes of final year from Singaporean, India and Thailand degree students' towards English. The researcher concluded that students had positive attitudes towards English and that their motivations for English were mostly instrumental.

Karahan (2007) conducted a study whose title is Language attitudes of Turkish Students towards the English language. This study examines the relationship between language attitudes and its use in Turkey. The sample included 190 eighth grade students of a private primary school in Adana, Turkey, where English is intensively taught. Results showed that although these students are exposed to English in a school environment more frequently than other students at public schools, they have only mildly positive attitudes; especially female students have higher rates.

(Lai, 2009) conducted a study entitled: Tracking language attitudes in postcolonial Hong Kong: interplay of localization, mainlandization, and internalization. This study reported a comparison between the results of the two surveys, which showed "Pragmatic Trilingualism" as a future trend for the younger generation of Hong Kong. 
Having experienced the postcolonial changes for twelve years, informants of the study also showed significantly more positive attitudes towards Putonghua than the counterparts in 2001.

Mamun (2012) tried to find out Students' Attitudes toward English: The Case of Life Science of Khulna University. The attitudes of undergraduate students of Life Science School of Khulna University toward English language. The findings suggest that the respondents were found to be positive towards English language and this could be attributed to the fact that respondents were instrumentally motivated towards English.

Mondal (2012) conducted a study entitled: Attitudes toward English among Bangladeshi Students: College level Education. The purpose of the study was to investigate Bangladeshi college level students' attitudes toward English. The findings revealed that the respondents showed positive attitudes towards English. They also felt that Bangladeshi English should be standardized.

AL-Noursi, (2013) carried out a study entitled: Attitudes toward Learning English: The case of the UAE Technology High School. This study investigated whether the students' attitudes is affected by the teacher's nativity. The findings showed that the vast majority of the subjects of the study had positive attitudes towards learning the English language in addition, the findings revealed that teacher's nativity (native speaker -vs. non- native speaker of English did not influence students' positive orientation toward the English language.

Kamil, (2014) in his study Language Attitudes of Iraqi native speakers of Arabic: A Sociolinguistic Investigation, he investigated language attitudes of Iraqi native speakers of Arabic toward two Arabic varieties in Iraqi standard Arabic and Iraqi Arabic. The findings showed that the differences in language attitudes between students and non-students were significant, i.e. students showed more favorable attitudes toward (SA) than (IA). Whereas non-students overwhelmingly preferred IA. No significant gender-based differences were found among participants.

Rukh (2014) conducted a study entitled: Students' attitudes toward English language learning and academic achievement: A case of Business students in Punjab. This study is investigating the English language learning and its association with their academic achievement. The findings of the study concluded that business students have a positive attitude toward English.

\section{The Problem of the Study}

The undergraduate students at AL- Quds Open University in Tulkarm Branch Study compulsory English courses .Students' interest, attitude and motivation for learning English and the chances of success in foreign language depend to a large extent on the favorable attitudes towards English language. But extensive literature survey suggests that the attitude toward English of the undergraduate students of Al-Quds Open University/Tulkarm Branch has not been studied. Thus, it is relevant to discover the attitudes of the target population toward English language.

\section{Purpose of the Study}

This study investigated the attitudes toward English among Al-Quds Open University students in Tulkarm branch, Palestine. These data were used to determine whether there are significant differences in attitudes toward English among Al-Quds Open University students due to gender and faculty and academic level.

\section{Research Questions}

The following research questions were asked:

1. What are Al-Quds Open University students' attitudes toward English in Tulkarm Branch?

2. Are there differences in attitudes toward English among Al-Quds Open University students in Tulkarm Branch due to gender?

3. Are there differences in attitudes toward English among Al-Quds Open University students in Tulkarm Branch due to faculty?

4. Are there differences in attitudes toward English among Al-Quds Open University students in Tulkarm Branch due to academic level? 


\section{Limitation of the Study}

This study was limited to 180 male and female students who were randomly chosen from AL- Quds Open University/ Tulkarm Branch to find out their attitudes toward English. These students were studying in the summer course of the academic year 2014/2015. They were in the years from first to fourth at the university and were distributed on four faculties.

\section{Methodology}

The research design consisted of the following sections:

1. Population of the study

2. Sample of the study

3. Instrumentation

4. Statistical analysis and results

\subsection{Population of the Study}

The population of the study consisted of all Al-Quds Open University students in Tulkarm Branch (701 males and 1093 females) who were studying in the summer course of the academic year (2014-2015).

\subsection{Sample of the Study}

A stratified random sample of the study consisted of (70 male and 110 female) students were selected according to gender and (10\% of the population) (see Table 1$)$.

Table 1. Distribution of the Study Sample According to Gender $(\mathrm{N}=180)$

\begin{tabular}{llcc}
\hline Variable & Level & Frequency & Percent \\
\hline Gender & Male & 70 & 39.0 \\
& Female & 110 & 61.0 \\
Faculty & Technology and applied sciences & 71 & 39.4 \\
& Social Development & 10 & 05.6 \\
& Administrative Sciences & 85 & 47.2 \\
& Education & 14 & 07.8 \\
Academic & $1^{\text {st }}$ year & 28 & 15.6 \\
level & $2^{\text {nd }}$ year & 42 & 23.3 \\
& $3^{\text {rd }}$ year & 61 & 33.9 \\
& $4^{\text {th }}$ year & 49 & 27.2 \\
\hline
\end{tabular}

\subsection{Instrument}

Data were collected through a questionnaire. The first part of the questionnaire required personal information: gender, faculty, year of study. The second part of the questionnaire asked the students about their attitudes toward English on the basis of five-point Likert scale. (See appendix for the items). The questionnaire was presented to students at Al-Quds Open University- Tulkarm Branch.

\subsection{Validity and Reliability of the Instrument}

To validate the questionnaire, the researcher gave it to colleagues who hold $\mathrm{PhDs}$ in education, some of their suggestions and modifications were incorporated into the questionnaire. The reliability (internal consistency) of the ATEQ was explored using Cronbach's alpha $(\alpha)$. The Cronbach's $\alpha$ for the ATEQ was (0.91). This reliability makes the instrument suitable for this study.

\subsection{Statistical Analysis and Results}

The following key has been used to judge the paragraphs of the questionnaires: An average of less than 2.33 indicates a low score; an average of $2.33-3.67$, indicates a moderate score; an average of more than 3.67 indicates a high score. 


\section{Results}

8.1 Results Related to the First Question: What are Al-Quds Open University Students in Tulkarm Branch Attitudes toward English?

To answer this question, means and standard deviations of each item were calculated as shown in Table 2.

Table 2. Means and Standard Deviations of the Attitudes Toward English among Al-Quds Open University Students in Tulkarm Branch, Sorted by Averages

\begin{tabular}{|c|c|c|c|c|}
\hline No & Items & Mean & SD & Estimation \\
\hline 16 & English helps me when I travel abroad. & 4.49 & 0.68 & High \\
\hline 8 & $\begin{array}{l}\text { Mastering English provides me with bigger chance to get a job in } \\
\text { the future. }\end{array}$ & 4.40 & 0.86 & High \\
\hline 3 & English helps me understand foreigners and their civilizations. & 4.30 & 0.88 & High \\
\hline 2 & $\begin{array}{l}\text { Learning English makes me able to read newspapers, magazines } \\
\text { and books in English. }\end{array}$ & 4.28 & 0.80 & High \\
\hline 5 & $\begin{array}{l}\text { Learning English enables me to read directions and instructions } \\
\text { for imported things. }\end{array}$ & 4.27 & 0.81 & High \\
\hline 28 & I feel that I need English when I finish my study. & 4.26 & 0.90 & High \\
\hline 30 & $\begin{array}{l}\text { The decision of starting teaching English from the first basic class } \\
\text { is a right decision }\end{array}$ & 4.23 & 1.20 & High \\
\hline 6 & English gives me better opportunity to go through the internet. & 4.23 & 0.80 & High \\
\hline 1 & English helps me interact with others through social media sites. & 4.19 & 0.75 & High \\
\hline 25 & $\begin{array}{l}\text { My knowledge of English makes me more confident when I meet } \\
\text { people who are not Arabs. }\end{array}$ & 4.08 & 0.75 & High \\
\hline 27 & Everyone has to learn English regardless of his study level. & 4.02 & 1.02 & High \\
\hline 9 & $\begin{array}{l}\text { I enjoy being with people who speak the English language } \\
\text { whether they are native or non-native speakers. }\end{array}$ & 3.97 & 1.06 & High \\
\hline 23 & $\begin{array}{l}\text { I think that English is more successful than other foreign } \\
\text { languages. }\end{array}$ & 3.89 & 1.10 & High \\
\hline 14 & $\begin{array}{l}\text { I feel proud when my family and my friends feel happy when I } \\
\text { speak English. }\end{array}$ & 3.88 & 0.97 & High \\
\hline 11 & I enjoy speaking English with foreigners. & 3.87 & 0.98 & High \\
\hline 29 & English classes have to be increased in schools. & 3.85 & 1.19 & High \\
\hline 15 & $\begin{array}{l}\text { I like the effect of English when it is spoken by its original } \\
\text { natives }\end{array}$ & 3.83 & 1.00 & High \\
\hline 18 & I listen to English in order to improve my English language. & 3.83 & 1.01 & High \\
\hline 20 & I like to be able to think in English as its native speakers do & 3.82 & 1.02 & High \\
\hline 13 & $\begin{array}{l}\text { Knowing English reflects the depth of one's culture and its } \\
\text { largeness. }\end{array}$ & 3.80 & 1.12 & High \\
\hline 7 & Learning English makes me feel with assurance & 3.79 & 1.04 & High \\
\hline 21 & When I speak English I feel as if I am a different person. & 3.73 & 1.03 & High \\
\hline 10 & $\begin{array}{l}\text { I enjoy speaking English with those who speak my mother } \\
\text { tongue. }\end{array}$ & 3.70 & 1.11 & High \\
\hline 26 & $\begin{array}{l}\text { Mastering English makes me feel that I more successful than } \\
\text { others }\end{array}$ & 3.69 & 0.98 & high \\
\hline 17 & $\begin{array}{l}\text { I enjoy television films and the programs which are presented in } \\
\text { English. }\end{array}$ & 3.66 & 1.12 & Moderate \\
\hline 24 & I feel confident when I use English. & 3.65 & 0.98 & Moderate \\
\hline 22 & The more I use English in my daily life the more confidence I get. & 3.61 & 1.09 & Moderate \\
\hline 12 & $\begin{array}{l}\text { Learning English makes me appreciate the Arabic Language in a } \\
\text { better form. }\end{array}$ & 3.60 & 1.04 & Moderate \\
\hline 19 & $\begin{array}{l}\text { I like studying English even if it is not obligatory at the } \\
\text { university. }\end{array}$ & 3.59 & 1.19 & Moderate \\
\hline 4 & I wait for lectures in English eagerly. & 3.11 & 1.12 & Moderate \\
\hline \multicolumn{2}{|r|}{ The whole instrument } & 3.92 & 0.52 & High \\
\hline
\end{tabular}


Table 2 shows that item "English helps me when I travel abroad "gets rank one with its mean value (4.49) and standard deviation (0.68). Also, the item "Mastering English provides me with bigger chance to get a job in the future "gets rank two with its mean value (4.40) and standard deviation (0.86). Likewise, the item "English helps me understand foreigners and their civilizations "gets rank three with its mean value (4.30) and standard deviation (0.88). The mean for whole Attitudes toward English Questionnaire was (3.92), and it meets the estimation of Likert scale of high degree.

\subsection{Differences Due to Gender}

To answer the second question of the study, are there differences in attitudes toward English among Al-Quds Open University students in Tulkarm Branch due to gender?

The researcher used the t-test to analyze the data from the questionnaire.

Table 3. T-test of the Differences among the Means of Attitudes Level toward English Due to Gender

\begin{tabular}{llllll}
\hline Variable & N & Mean & S.d & t-value & Sig \\
\hline Male & 70 & 3.79 & 0.65 & 2.53 & 0.01 \\
Female & 110 & 4.00 & 0.47 & & \\
\hline
\end{tabular}

Table 3 shows that the means of the attitudes level toward English for the males were (3.79) and the means of the attitudes level toward English for the females were (4.00), and significant gender main effect $(t=2.53, p=0.01)$.

\subsection{Differences Due to Faculty}

To answer the third question of the study, Are there differences in attitudes toward English among Al-Quds Open University students in Tulkarm branch due to faculty?

An analysis of variance (ANOVA) was used to compare the differences in attitudes toward English among Al-Quds Open University students in Tulkarm branch due to faculty. Table 4 and table 5 show the results.

Table 4. Means, Standard Deviations of Attitudes toward English among Al-Quds Open University Students in Tulkarm Branch Due to Due Faculty

\begin{tabular}{lll}
\hline Faculty & N & Mean \\
\hline Technology and applied sciences & 71 & 3.86 \\
Social Development & 10 & 3.95 \\
Economic Sciences & 85 & 3.93 \\
Education & 14 & 4.13 \\
\hline
\end{tabular}

Table 5. ANOVA in Attitudes toward English among Al-Quds Open University Students in Tulkarm Branch Due to Faculty

\begin{tabular}{llllll}
\hline Variance & Sum of squares & df & Mean square & F & P-value \\
\hline Between Groups & 0.90 & 3 & 0.30 & 0.97 & 0.41 \\
Within Groups & 54.64 & 176 & 0.31 & & \\
Total & 55.54 & 179 & & & \\
\hline
\end{tabular}

Table 5. shows that there are no statistical significant differences in attitudes toward English among Al-Quds Open University students in Tulkarm branch to due faculty.

8.4 Differences Due to Academic Level

To answer the third question of the study, Are there differences in attitudes toward English among Al-Quds Open University students in Tulkarm Branch due to academic level?

An analysis of variance (ANOVA) was used to compare the differences in attitudes toward English among Al-Quds Open University students in Tulkarm branch due to academic level. Table 6 and table 7 show the results. 
Table 6. Means, Standard Deviations of Attitudes toward English among Al-Quds Open University Students in Tulkarm Branch Due to Academic Level

\begin{tabular}{lll}
\hline academic level & $\mathrm{N}$ & Mean \\
\hline $1^{\text {st }}$ year & 28 & 3.92 \\
$2^{\text {nd }}$ year & 42 & 3.71 \\
$3^{\text {rd }}$ year & 61 & 3.95 \\
$4^{\text {th }}$ year & 49 & 4.05 \\
\hline
\end{tabular}

Table 7. ANOVA in Attitudes Towards English among Al-Quds Open University Students in Tulkarm Branch Due to Academic Level

\begin{tabular}{llllll}
\hline Variance & Sum of squares & df & Mean square & F & P-value \\
\hline Between Groups & 2.62 & 3 & 0.87 & 2.91 & 0.03 \\
Within Groups & 52.9 & 176 & 0.30 & & \\
Total & 55.52 & 179 & & & \\
\hline
\end{tabular}

Table 7 shows that there are statistical significant differences in attitudes toward English among Al-Quds Open University students in Tulkarm Branch due to academic level. L.S.D post hoc test (table) was utilized to detect the group $(\mathrm{s})$ that differed statistically $(\mathrm{p} \leq 0.05)$ among students groups. The L.S.D post hoc results were cleared in Table 8.

Table 8. Results of post hoc Test Comparisons Using L.S.D Method for Independent Variable Academic Level

\begin{tabular}{lllll}
\hline & $1^{\text {st }}$ year & $2^{\text {nd }}$ year & $3^{\text {rd }}$ year & $4^{\text {th }}$ year \\
\hline $1^{\text {st }}$ year & & 0.21 & 0.03 & 0.13 \\
$2^{\text {nd }}$ year & 0.21 & & $0.24^{*}$ & $0.34^{*}$ \\
$3^{\text {rd }}$ year & 0.03 & $0.24 *$ & & 0.10 \\
$4^{\text {th }}$ year & 0.13 & $0.34^{*}$ & 0.10 & \\
\hline
\end{tabular}

Table 8. shows that there is a significant difference at $(\alpha=0.05)$ in attitudes toward English among Al-Quds Open University students in Tulkarm Branch due to academic level between $4^{\text {th }}$ year and $2^{\text {nd }}$ year in favor of $4^{\text {th }}$ year, and between $4^{\text {th }}$ year and $3^{\text {rd }}$ year in favor of $4^{\text {th }}$ year.

\section{Discussion of Results}

The main purpose of the study was to investigate the attitudes of AL- Quds Open University - Tulkarm Branch students about English by asking them about their opinions. The results revealed that the respondents realized the necessity of learning English in the era of globalization and they reported their positive attitudes toward English. These results seemed to be in an agreement of the results of Buschenhofen (1998) which showed that students generally have positive attitudes toward English. Moreover, the results of this study also agree with the results of Kwofie's study (2001) as students in this study have favorable attitudes toward English because they believed that English has its communicative, instrumental and educational values. The results of Karahan's study (2007) which revealed that female students generally had higher rates than male students indicating more positive attitudes toward the use of English in Turkey. These results agreed with the results of the present study which showed the same conclusion as indicated in table 3 in the study that females have significantly higher positive attitudes toward English than males do. This phenomenon can be attributed to more than one factor. First, sociolinguistically speaking, it has been said that females are evaluated by the way they speak rather than the way they work. So they tend to use English as they believe that speaking a foreign language in general and English in particular is something prestigious. Second, studies have showed that females are more able to learn languages than males do. Third, it is noticed that the number of females who major in English in different universities is greater than the number of males. For example, specifically speaking, in AL- Quds Open University/ Tulkarm Branch, in the academic year 20142015, there are 271 females and 43 males who major in English.

\section{Conclusions and Recommendations}

\subsection{Conclusions}

The study found a generally positive attitude toward English. Moreover; the following brief conclusions were also 
reached:

1. In general both males and females have positive attitude towards English at AL-Quds Open University/ Tulkarm Branch.

2. Student's gender affects his/her attitude towards English, i.e. females has more positive attitude towards English than males do.

3. Student's faculty (specialization) does not affect his/ her attitude towards English.

4. Student's academic level affects his/ her attitude towards English.

From these conclusions, attitude toward English could be a call for other researchers to prove or refute the abovementioned conclusions.

\subsection{Recommendations}

Based on the conclusions made, the following recommendations are forwarded:

1. Universities are recommended to offer more English communication courses to let students improve their language.

2. Students are recommended to arrange co-curricular English activities in special meetings among themselves to use English in speaking and writing.

3. Teachers are recommended to encourage their students to use English as much as possible to become better at using the language.

4. Researchers are recommended to carry out further studies on students' attitude towards English.

\section{References}

AL-Haq, F. A.A. (2000). Changes in the attitudes of Jordanian University students to the Hebrew language. Journal of Sociolinguistics, 4(2), 263-273. http://dx.doi.org/10.1111/1467-9481.00114

AL- Noursi, O. (2013). Attitudes towards Learning English: The case of the UAE Technological High School. Educational Research, 4(1), 201-30.

Ardeo, J.M.G. (2003). Attitudes towards English and ESP acquisition as an L2 or at L3 University. IBERICA, 6, 109-133.

Baker, C. (1992). Attitudes and Language. Clevedon: Multilingual Maters.

Buschenhofen, P. (1998). English language attitudes of final-year high school and first- year university students in Papua New Guinea. Asian Journal of English Language Teaching, 8, 93-116.

Donitsa-Schmidt, et.al. (2004). The effects of teaching spoken Arabic on students' attitudes and motivation in Israel. The Modern Language, 88(I), 217-228. http://dx.doi.org/10.1111/j.0026-7902.2004.00226.x

El-Dash, L.G., \& Busnardo, J. (2001). Brazilian attitudes toward English: Dimensions of status and solidarity. International Journal of Applied Sciences, 11(1), 57-74.

Gardner, R., C., Lalonde, R.N., \& Macpherson. (1985). Social factors in second language attrition. Language learning, 35, 519-540. http://dx.doi.org/10.1111/j.1467-1770.1985.tb00359.x

Guerini, F. (2007). Multilingualism and language attitudes in Ghana: A preliminary survey, $6^{\text {th }}$ International Symposium on Bilingualism, University of Hamburg, Germany.

EL-Dash H.L.G., \& Busnardo J. (2001). Brazilian attitudes toward English: Dimensions of status nd solidarity. International Journal of Applied Sciences, 11(1), 57-74.

Kamil, M.M. (2014). Language attitudes of Iraqi native speakers of Arabic: A Sociolinguistic Investigation. Unpublished M.A. Thesis.

Karahan, F. (2007). Language attitudes of Turkish students towards the English language and its use in Turkish context. Journal of Arts and sciences, Sayt, 7

Kwofie, R.J. (2001). A pilot study of language attitudes among University of Cape Coast students, Unpublished Long Essay, University of Cape Coast, Cape Coast.

Lai, M. L. (2009). I love Cantonese but I want English- A qualitative account of Hong Kong secondary Language 
attitudes. The Asia Education Research, 18(1), 79-92.

Lin, H., \& Warden, C. (1998). Different attitudes among non-English major EFL students. The Internet TESL Journal, 4(10). Retrieved June 2003 from http: //iteslj.org/

Lindemann, S. (2002). Listening with an attitude: A model of native -speaker comprehension of non- native speakers in the United States. Language in Society, 31(3), 419-41. http://dx.doi.org/10.1017/S0047404502020286

Bernaus M., Masgort A.M., Gardener R.C., \& Reyes E. (2004). Motivation and attitudes towards learning languages in multicultural classrooms. The International Journal of Multilingualism, 1(2), 75-89. http://dx.doi.org/10.1080/14790710408668180

Mamun, Sk., etal. (2012). Students' Attitudes toward English: The case of Life Science School of Khulna University. International Review of Social Sciences and Humanities, 3(1), 200-209.

Mantle- Bromley, C. (1995). Positive attitudes and realistic beliefs: Links to proficiency. The modern Language Journal, 79(3), 372- 386. http://dx.doi.org/10.1111/j.1540-4781.1995.tb01114.x

Marley, D. (2003). Language attitudes in Morocco following recent changes in language Policy. Language Policy, 3(1), 25-46. http://dx.doi.org/10.1023/B:LPOL.0000017724.16833.66

Mondal, N.K. (2012). Attitudes towards English among Bangladeshi students: College level Education. Education Academia Arena, 4(3), 24-30.

Rukh, S. (2014). Students' attitudes towards English language learning and academic achievement: A case of business students in Punjab. European Academic Research, 2(4), 5596-5612.

Samonte B. J. (1981). Attitudes of college students towards English as a second language. Unpublished Thesis, University of Santo Thomas, Manila, Philippines.

Shaw, W.D. (1983). Asian student attitudes towards English. In L.E. Smith (ed.), Readings in English as an International Language, 21(33), Great Britain: Pergamon Press Ltd.

Skehan, P. (1989). Individual Differences in Second Language Learning. London: Routledge.

Starks, D., \& Paltridge, B. (1996). A note on using sociolinguistics methods to study non-native attitudes towards English. World-Englishes, 15(2), 217-224. http://dx.doi.org/10.1111/j.1467-971X.1996.tb00107.x

Wenden, A.L. (1991). Learner strategies for learner autonomy. London: Prantice Hall.

Zhou, M. (1991). The spread of Putonghua and Language attitude changes in Shanghai and Guangzhou China. Journal of Asian communication, 11(2002), 231-253. 